\title{
THE NETHERLANDS: GROUND TRANSPORT BELOW SEA LEVEL
}

Wim Korver, Gijsbertus R.M. Jansen and Piet H.L. Bovy

\section{TRANSPORTATION DETERMINANTS}

\subsection{Population and geography}

The Netherlands are situated at the mouth of the rivers Rhine, Maas and Schelde and border on the North Sea. The highest point $(321 \mathrm{~m})$ is in the extreme south-east and the lowest $(6.70 \mathrm{~m}$ below sea level) near the city of Rotterdam. In total about a quarter of the land area is below sea level.

The population of the Netherlands has increased from $12.2 \mathrm{~m}$ in 1965 to $14.8 \mathrm{~m}$ in 1989. The average annual growth rate declined from $1.5 \%$ between $1945-1965$ to $0.6 \%$ in 1989. The large decrease of the birth rate has resulted in a drop in the number of young people and sharp reduction of the share of young people in the population. At the same time the number of inhabitants aged 20-64 rose due to the high birth rates of twenty years ago.

The size of households has changed significantly during the last 20 years, the average household size fell from 3.2 to 2.4 persons. This reduction stems mainly from a dramatic increase in the number of one and two-person households: its proportion increased to $54 \%$ in 1985 . It will be clear that this development affected the population of the cities and the need for housing significantly. The diversity in household types changed as well. It is no longer possible to typecast a multi-person household by two 329

I. Salomon et al. (eds.), A Billion Trips a Day, 329-348.

() 1993 Kluwer Academic Publishers. Printed in the Netherlands. 
parents and two or more children. Other household types, like those with a single parent, or with two adults without children, became more common in the Netherlands.

The population density is high in the Netherlands: 438 inhabitants per square kilometre. Figure 19.1 shows that the highest population densities are found in the western part of the Netherlands: the so-called "Randstad", a ring-shaped conglomeration of contiguous cities including Amsterdam and Rotterdam, and a total population of about $6 \mathrm{~m}$.

The country may be classified as highly urbanized, dominated by a large number of medium-sized cities. Rural villages where people are self supporting and are not interacting heavily with the outside world, are very rare. Almost everywhere in the country a small town is within 10 kilometre distance. Forty three percent of the population lives in cities with more than 50,000 inhabitants. A rather small percentage (12\%) of the population lives in very small (under 19000 inhabitants) and also, $12 \%$ live in cities of over 250,000 population [CBS, 1990a].

\subsection{The labour market}

The Dutch labour force amounts to 6.8 million, including the unemployed. This implies a participation rate of about $67 \%$ of the 15-65 year old population. Compared with other European countries, the Netherlands has a rather low participation rate. The main reason is the small labour force participation rate of married women. Table 19.1 confirms that a relatively small proportion of the women have a job, i.e. $51 \%$, which is much lower than that of the male population (82\%).

The figures show large differences in women's participation by age groups. The participation for the 15-24 year age bracket, however, is (almost) the same for both sexes. In older age brackets the participation of (married) women is much lower.

In absolute numbers, it can be seen that the labour force has grown especially due to the number of female workers: it almost doubled. A comparison of Tables 19.1 and 19.2, shows that the number of employed people increased, whereas employment measured in person-years was constant. This difference can be explained by the increase in the number of part-time jobs and by the significant rise of unemployment.

The Dutch economy is heavily service-oriented: private services account for $51 \%$ of the employment. Together with the share of the government (10\%), this implies that $70 \%$ of the jobs are related to services. Within the service sector, transport, storage and communication branches together account for a quarter of the jobs. The other economic sectors show a decline or a stabilization. 


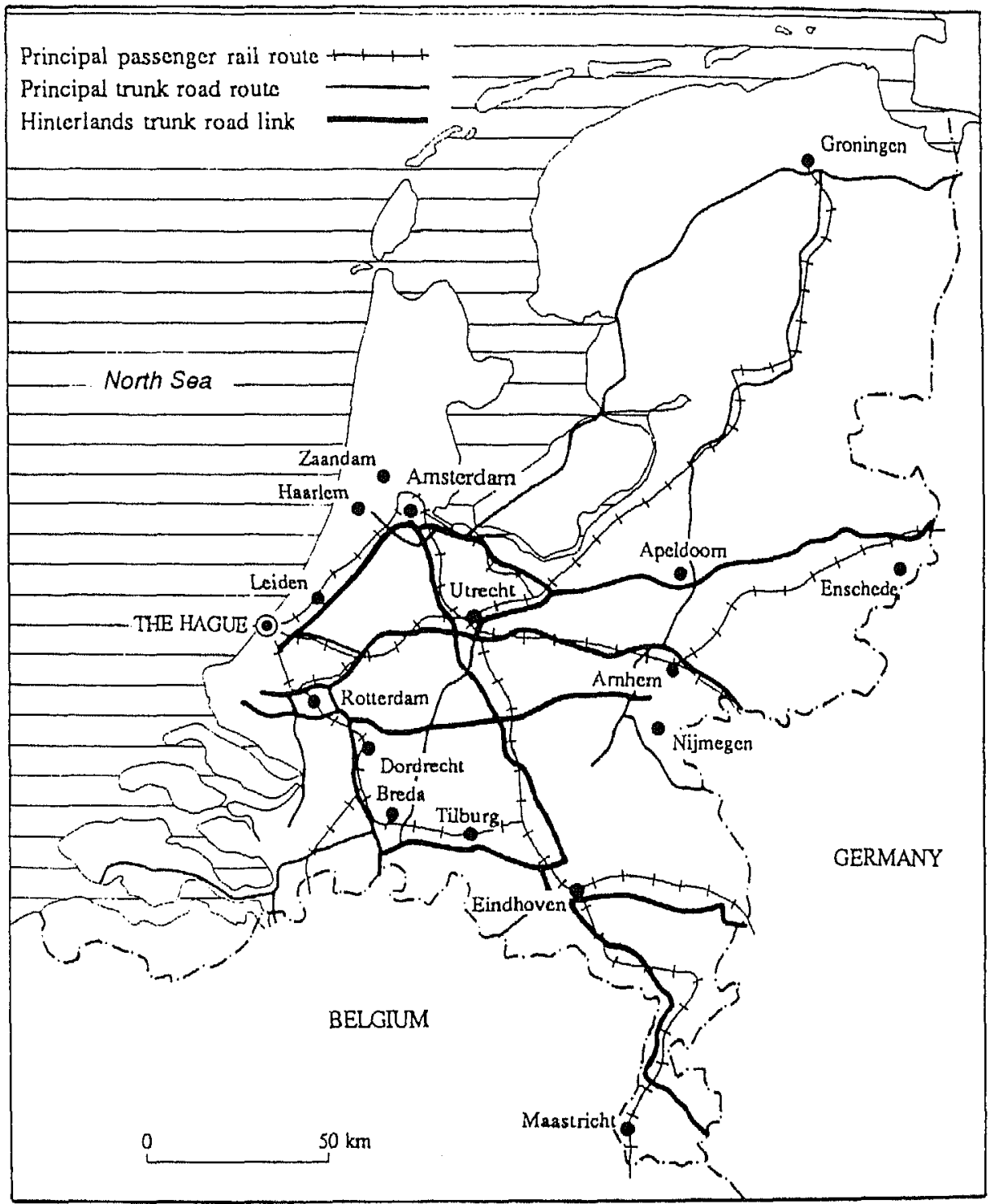

Figure 19.1: Municipalities of over 100,000 inhabitants and provinces, and the main road and railway networks in the Netherlands Source: The Ministry of Transport and Public Works, 1990; The National Bureau of Statistics, 1990A 
TABLE 19.1

The participation in the labour market by age and sex

\begin{tabular}{|c|c|c|c|c|}
\hline & \multicolumn{2}{|c|}{ Labour force (thousands) } & \multicolumn{2}{|c|}{ Participation rate $(\%)$} \\
\hline & 1975 & 1988 & 1975 & 1988 \\
\hline Men: $14-24$ years & 643 & 772 & 50 & 62 \\
\hline $25-44$ years & 1,884 & 2,305 & 99 & 98 \\
\hline $45-64$ years & 1,034 & 1,073 & 80 & 73 \\
\hline Total & 3,561 & 4,150 & 79 & 82 \\
\hline Women: $14-24$ years & 550 & 712 & 45 & 60 \\
\hline $25-44$ years & 563 & 1,413 & 32 & 60 \\
\hline $45-64$ years & 258 & 482 & 19 & 32 \\
\hline Total & 1,371 & 2,607 & 31 & 51 \\
\hline All: $14-24$ years & 1,193 & 1,484 & 47 & 61 \\
\hline 25.44 years & 2,447 & 3,718 & 67 & 79 \\
\hline $45-64$ years & 1,292 & 1,555 & 48 & 52 \\
\hline Total & 4,932 & 6,757 & 55 & 67 \\
\hline
\end{tabular}

Source: The National Bureau of Statistics, 1990A

\subsection{The educational system}

In the Netherlands compulsory school age is from 5 to 16 . The school system consists of 8 years primary school starting at the age of 4 , which is followed by a secondary school at various levels, lasting 4 to 6 years depending on the level. After this phase pupils can choose from three possibilities: taking a job, vocational education (several levels) or university education. In $1988 / 9$ there were 3.8 million students and pupils (compared with 3.9 million in 1975). Of these, 1.5 million were in primary education, 990,000 in secondary, 465,000 in vocational education and 158,000 university students. This amounts to 21.3 full time students per 100,000 inhabitants.

Over the last 12 years, a steady decline in the number of pupils in primary schools and growing enrolment in higher education can be noticed. 
TABLE 19.2

Distribution of employment by different economic sectors (in thousand person-years)

\begin{tabular}{|c|c|c|c|c|}
\hline & 1978 & 1980 & 1985 & 1988 \\
\hline Agriculture and fishing & 285 & 278 & 271 & 266 \\
\hline Manufacturing and public utilities & 1,065 & 1,047 & 945 & 972 \\
\hline Construction & 445 & 449 & 330 & 358 \\
\hline Private services & 2,228 & 2,319 & 2,279 & 2,472 \\
\hline Total private enterprise sector & 4,023 & 4,093 & 3,825 & 4,068 \\
\hline Government & 690 & 714 & 736 & 744 \\
\hline Total & 4,713 & 4,807 & 4,561 & 4,812 \\
\hline
\end{tabular}

Source: OECD,1989

The shares of female students in secondary, vocational and university education were $49 \%, 46 \%$ and $39 \%$ respectively.

Apart from the full-time education there are numerous part-time courses offering the same diplomas and qualifications as the full-time institutions. The number of participants is significant: 700,000 .

\subsection{The economy}

In 1988 the gross domestic product (GDP) in purchaser's values was about 451 billion Dfl. (about 194 billion ECU), i.e about 13,002 ECU per capita. This means that the Netherlands has the 6th largest economy in the EC. In terms of GDP per capita it is slightly above EC average. The average annual growth rate of the GDP amounted to $1 \%$ in the early 80 's, gradually increasing after 1985 to approx. $3 \%$.

Export plays a very important role in the Netherlands: almost $50 \%$ of the GDP consists of export of goods and services. The improved economic situation is for a major part attributed to export of goods and services. The major trade partners are Germany, Great Britain and Belgium.

The transport sector is important to the Dutch economy; it contributed $7 \%$ to the net domestic product at factor cost in 1987. The share in export is even higher: $8 \%$. The contribution of Dutch transportation firms to the balance of payments is almost 15 billion Dfl. This reflects the very strong Dutch position in the transport field. The country can be seen as the main distributional hub in North-West Europe.

Central government spends about 7.4 billion Dfl. per year on traffic and transport, of 
which 4 billion on public transport, 2.6 billion on roads and 0.7 billion on waterways. The investments of private firms in transport equipment are fluctuating strongly from year to year. In 1988 private firms invested approx. 11.1 billion Dfl. in transport equipment.

The favourable geographical position and the excellent infrastructure offer the country access to a hinterland extending across a considerable part of Western and central Europe. About a quarter of the maritime cargo loaded or unloaded on behalf of the countries of the EC passes through Dutch ports. The Rotterdam port has also become the major container port in Western Europe, handling over 2.2 million containers in 1989 [Roads, 1987; CBS, 1989C]. Dutch road network hauliers account for approx. $30 \%$ of all cross-national freight transport on the road within the EC.

Table 19.3 shows the overwhelming importance of Rotterdam and other sea-ports for goods transport. The figures further reveal that the majority of the international goods transport to the hinterland takes place by inland shipping, whereas the rail mode can be neglected. This is a marked difference with the other countries in Northwest Europe.

Household expenditures remained the same in the first half of the 1980's, but resumed their growth in the second half. The share of transport in total household expenditure is approximately $11.4 \%$ (NEI, 1989). Between 1980-1985 the expenditures for public

TABLE 19.3

International and inland transport of goods in 1987 (x 1000 ton)

\begin{tabular}{lrrrrr}
\hline & $\begin{array}{c}\text { Sea- } \\
\text { transport }\end{array}$ & $\begin{array}{c}\text { Inland } \\
\text { shipping }\end{array}$ & Rail & Road & Air \\
\hline Unloaded goods & 241,782 & 42,597 & 4,308 & 48,976 & 237 \\
Loaded goods & 73,200 & 103,452 & 7,219 & 46,925 & 216 \\
Inland goods transport & - & 89,737 & 5,224 & 399,184 & - \\
\hline
\end{tabular}

Source: The National Bureau of Statistics, $1989 \mathrm{C}$

transport increased, both for car-owners and non car-owners. The household expenditure for transport decreased by $4 \%$ in 1988, while at the same time total household expenditure rose by $1.3 \%$. This can be explained by the strong fall of car sales (from 556,000 in 1987 to 481,000 in 1988) and lower fuel prices. 


\subsection{The temporal structure of activities}

The most common work schedule is still the five day work week with usual working hours from about $8.30 \mathrm{a} . \mathrm{m}$. till $5.00 \mathrm{p} . \mathrm{m}$. Lunch is usually consumed at the work-place, and only a minority of the employees have lunch at home or in a restaurant. Part-time employed people show a strong preference for working during morning hours. This implies that work travel in the morning rush hour is heavier and will not diminish quickly due to the increase of part-time employment. However, some influence from the shift to part-time work is noticeable: quite a number of people opt for four days working, and Friday is gradually becoming a third day of the weekend.

The average number of leave-days is 25 a year, but the majority of the employees also participate in a special labour time reduction scheme, which gives them an additional 5 leave-days. The most popular vacation period is July and August. In this period most people are on vacation for 3 weeks. Additional short vacations (sun or snow) in the other months of the year are becoming more and more popular.

The school schedule is five days as well, and school also starts at around $8.30 \mathrm{a} . \mathrm{m}$. and ends around $3.30 \mathrm{p} . \mathrm{m}$. School vacations are in the summer during July and August and in winter two weeks at Christmas, one week in the autumn and one week at Easter. Most primary school pupils have lunch at home, whereas the older pupils usually consume lunch at school.

Shops are open Monday till Saturday from 9 a.m. till 6 p.m. and one evening per week (Thursday or Friday) from 7 p.m. till 9 p.m (late night shopping). Saturday is the most popular shopping day.

In general, little variation or flexibility in activity schedules is found in the Netherlands. Figure 19.2 depicts the distribution of personal trips by hour of day, which reflects the activity pattern mentioned above. It shows that most travel takes place in the morning peak from 7-9, whereas the busiest hours are between 8-9 and 16-17. With respect to the activities that generate peak travel, it can be seen that the share of work travel is larger in the morning peak, in contrast to the larger share of shopping and other trips in the evening peak. For car travel only the morning peak is larger than the evening peak, mainly because car use in work travel is relatively high.

\section{THE TRANSPORTATION SYSTEM}

\subsection{The structure of the public transport system}

The responsibility for the provision of public transport rests with municipalities and 
central government. Nine major municipalities have their own companies and public transport services are being run as a municipal undertaking. Forty other municipalities have contracts with regional bus companies to provide subsidized services. Rural and inter-urban services are operated by regional bus companies, each with a license to provide scheduled services within a certain region; together they form a syndicate known as the ESO. Finally, the Dutch Railways (NS), which is an independent state owned company, operates an extensive rail network with intercity and local services throughout the country. The cooperation between these several public transport companies is in some cases badly organized. For that reason the central government is planning to organize public transport more on a fully integrated regional basis, similar to the German "Verkehrsverbund" (traffic airline) model. Regional bus companies and urban public transport companies in particular will have to cooperate more than they are used to.

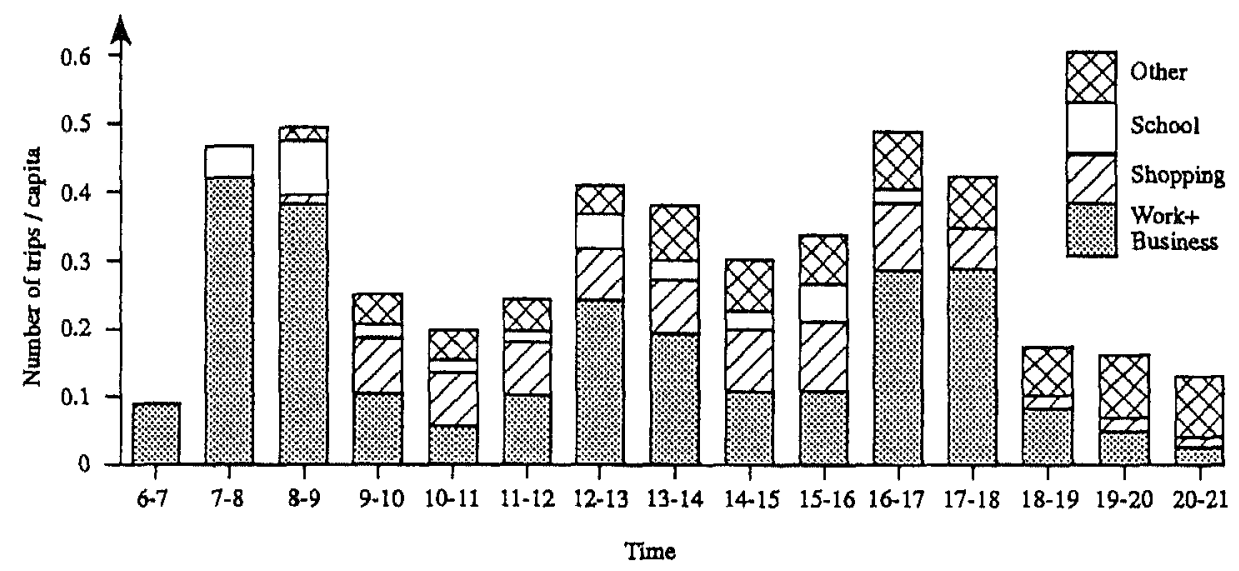

Figure 19.2: Number of trips per capita by hour and purpose (workdays). Source: The National Bureau of Statistics, 1989B

In the early 1950's, operating deficits began to emerge in several cities. In the 1960's NS were confronted with operating deficits and finally, in the early 1970's, regional bus companies also showed operating deficits. Since 1972, deficits of all public transport operations have been met by the central government. The subsidy has increased to more than 3.5 billion Dfl. per year (about $60 \%$ of operating costs), only to match the operating deficits of the public transport companies. Further, the central government finances the costs of new infrastructure; $100 \%$ for the Railways and $80 \%$ for urban public transport. The Minister of Transport is responsible for the fare policy by setting the fares for bus, tram and metro and by approving train fares proposed by NS. 
To achieve harmonization, the central government introduced in 1980 a nation-wide fare structure and an integrated ticket system for all urban public transport and rural public transport by bus. In Table 19.4 some figures are given concerning the performance of public transport in the Netherlands.

The modal share of public transport decreased during the last two decades from $20 \%$ in 1970 (measured in passenger kilometres) to only $13 \%$ in 1988 . Central government has a firm policy to improve public transport, mainly in order to reduce both congestion and the pollution due to road traffic. In particular its share in commuting has to be increased. For that purpose it plans to invest approximately 20 billion Dfl. in the forthcoming twenty years in new public transport infrastructure (14 billion Dfl. for the railways and 6 billion Dfl. for urban public transport) [Ministry of Transport and Public Works, 1990].

TABLE 19.4

Supply and usage of public transport in the Netherlands in 1988

\begin{tabular}{lccc}
\hline & \multicolumn{2}{c}{ Supply } & \multicolumn{1}{c}{ Usage } \\
\cline { 3 - 4 } & $\begin{array}{c}\text { Network } \\
\text { length }\end{array}$ & $\begin{array}{c}\text { Seat km. } \\
\text { per year }\end{array}$ & $\begin{array}{c}\text { Passengers km. } \\
\text { per year }\end{array}$ \\
\hline km. & $\times 1.000 .000$ & $\times 1.000 .000$ \\
Rutch Railways & 2,828 & 26.0 & 9.8 \\
Urban Transport & 326,441 & 319.2 & 4.0 \\
Total & 29,269 & 45.1 & 2.5 \\
\hline
\end{tabular}

Source: The National Bureau of Statistics, $1989 \mathrm{C}$

\subsection{Car ownership and use}

Figure 19.3 shows that both car ownership and the number of driver's license holders increased rapidly. In the early 1980's growth in car ownership seemed to level off due to the economic recession, but recent statistics indicate that car ownership resumed its growth. In 1988 the Netherlands had approx. 8 million driver's licence holders which accounts to about 540 per 1,000 inhabitants. At the end of 1988 almost 5 million 
passenger cars were in operation, i.e. 329 per 1,000 inhabitants. Of all households $74 \%$ own at least one car and $13.3 \%$ own even two cars or more.

Long term forecasts of car ownership predict a significant further growth to 520 per 1000 inhabitants in 2010 [Van de Broecke, 1987]. Demographic and economic factors are mainly responsible for this growth.

The number of commercial vehicles also increased in the last decade, from 243,000 in 1965 to 558,000 in 1989 .

Car use also increased dramatically since 1970. Figure 19.3 shows that, just like car ownership, the growth of car use levelled off around 1980. However, in the second half of the 1980's car use started to rise again, due to better economic conditions. The growth of traffic volumes varies for different road classes. The highest growth occurred on the motorways, averaging about $7 \%$ a year (1985-1988). While traffic volumes on the Dutch motorways increase by $33 \%$ between $1980-1988$ whereas the length of the motorway network increased only by $17 \%$. The respective figures for provincial roads are $15 \%$ and $6 \%$; increasing congestion is therefore no surprise.

Apart from some short interruptions, fuel prices did not change much in 20 years. The price of fuel in 1989 was only $13 \%$ above the nominal fuel price in 1980, so in real terms fuel price decreased. The penetration of more energy-efficient cars implies a reduction of real fuel costs per kilometre. Average fuel efficiency improved from 9.2 $1 / 100 \mathrm{~km}$ in 1980 to $8.51 / 100 \mathrm{~km}$ in 1988 [CBS, 1989E].

Of car related prices only the sales price of cars increased in real terms, mainly due to higher taxes on new cars. Several taxes are imposed on cars:

- Purchase tax (BVB) of about $20 \%$ of the sales price plus VAT of $18.5 \%$.

- Ownership tax (road tax) which depends on the weight and the fuel type of the car. No VAT is counted over this tax. To give an example: The ownership tax for a normal gasoline car of $800 \mathrm{~kg}$. is $405 \mathrm{Dfl}$. per year, for the same car with a diesel engine $730 \mathrm{Dfl}$. per year and with LPG the tax is $921 \mathrm{Dfl}$. per year.

- Fuel taxes, which differ by fuel type. In the first half of 1990 taxes in Dfl. per litre by fuel type excluding VAT were $155 \%$ on unleaded fuel, $56 \%$ on diesel and zero on LPG. The respective prices, including VAT, were 1.61, $0.948,0.409$ Dfl. The large differences in price stem mainly from taxation.

The typical distribution of cars by fuel types is remarkable in the Netherlands: $78 \%$ gasoline, 10\% diesel and 12\% LPG (Liquid Petrol Gas). [The CBS, 1989E]. The average annual kilometrage driven by diesel and LPG cars is twice as large as that of gasoline cars (gasoline: $14,050 \mathrm{~km}$; diesel: $28,030 \mathrm{~km}$; LPG: $24,590 \mathrm{~km}$ ). Within two years after its introduction in 1987 unleaded gasoline had a market share of almost $30 \%$ of all gasoline sold. 


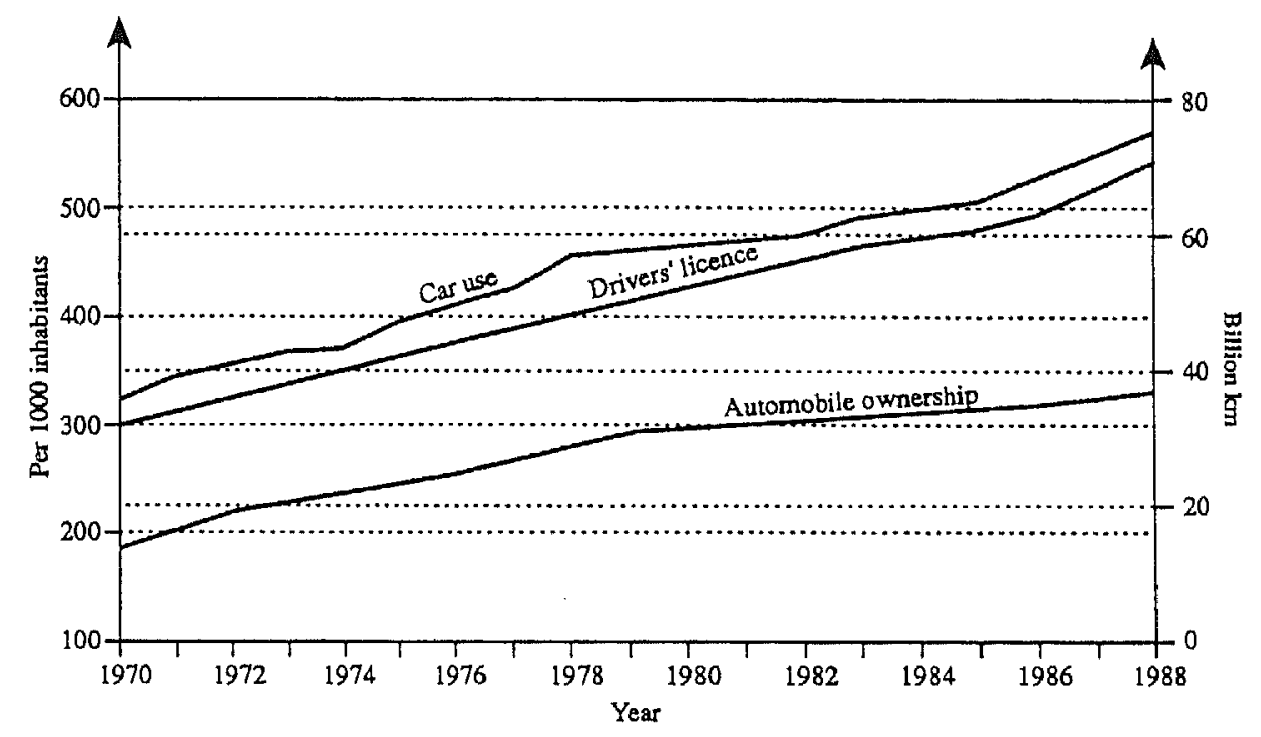

Figure 19.3: Car ownership, driver's license holders and total car use 1970-1988 Source: The National Bureau of Statistics, 1989C

\subsection{The urban and regional (metropolitan) transport system}

Both Amsterdam and Rotterdam have motorway rings around the urban areas. These ring roads contain the most heavily congested road sections in the Netherlands. Heavy congestion occurs especially at those places where rivers or channels are crossed.

The urban and metropolitan public transport system is supplied by several companies. First, in large metropolitan areas the Dutch Railways offers connections for intraregional trips, but the share of the railways in intra-regional travel is rather low. The share of the train is considerable in travel between central cities and the ex-urban areas, however, especially if measured in passenger kilometres. The train clearly specializes in long distance transport.

Amsterdam and Rotterdam have a limited underground system. The length of these systems is $18.7 \mathrm{~km}$. and $38.1 \mathrm{~km}$ respectively. Furthermore, four cities have a tramway system. The length of the tram networks is shown in Table 19.5. Other areas over 50,000 inhabitants offer only bus services.

\subsection{The interurban transport system}

The total length of the rail infrastructure is $2,828 \mathrm{~km}$ (1988), of which $1,767 \mathrm{~km}$ have two or more tracks. Figure 19.1 shows the railway network of the Netherlands. Since 
World War II its length has decreased, as have number of stations, but during the last decade some new lines and stations, mainly suburban, have been opened. The density of the national railway network is $76 \mathrm{~km}$ per $1000 \mathrm{~km}^{2}$.

TABLE 19.5

Supply of public transport in the four main cities in the Netherlands in 1988

\begin{tabular}{|c|c|c|c|c|}
\hline \multirow[t]{2}{*}{ Regions } & \multirow[t]{2}{*}{ No. Inhabitants } & \multicolumn{3}{|c|}{ Network length } \\
\hline & & Underground & Tram & Bus \\
\hline & $\times 1,000$ & & $\mathrm{~km}$ & \\
\hline Amsterdam & 1,038 & 19 & 77 & 235 \\
\hline Rotterdam & 1,039 & 38 & 67 & 240 \\
\hline The Hague & 683 & - & 79 & 109 \\
\hline Utrecht & 526 & - & 18 & 100 \\
\hline Total & 3,287 & 57 & 240 & 625 \\
\hline
\end{tabular}

Source: The National Bureau of Statistics, $1989 \mathrm{C}$ and 1990A

The motorway network in the Netherlands has a length of $2,048 \mathrm{~km}$ (1988), which implies a density of $50 \mathrm{~km}$ per $1000 \mathrm{~km}^{2}$. The motorway network has expanded rapidly since the 1960's; it doubled since 1970 (Figure 19.1). The main system connects virtually every city and region and it can be seen that the Dutch network is linked-up to the networks of neighbouring countries.

Most of the domestic air traffic is feeder service to Schiphol airport. Inter-urban air service can be neglected as a mode, as the distances are too short to be profitable.

\section{PATTERNS OF URBAN TRAVEL}

\subsection{Personal activities and trip making}

The number of trips per person by purpose do not differ much for different 
urbanization classes ${ }^{1}$ : only the number of shopping trips is larger for inhabitants of cities than for the inhabitants of villages (Table 19.6).

TABLE 19.6

Trips and kilometres travelled per capita per day and average trip length in $\mathrm{km}$ for different purposes and urbanization classes (1987)

\begin{tabular}{|c|c|c|c|c|c|c|}
\hline Urbanization class & Home/work & Business & Shopping & Education & Leisure & Total \\
\hline \multicolumn{7}{|l|}{ Trips: } \\
\hline Rural villages & 0.62 & 0.15 & 0.74 & 0.19 & 1.59 & 3.29 \\
\hline Urban villages & 0.59 & 0.14 & 0.86 & 0.19 & 1.66 & 3.44 \\
\hline Cities & 0.59 & 0.13 & 0.97 & 0.19 & 1.60 & 3.48 \\
\hline All classes & 0.59 & 0.13 & 0.90 & 0.19 & 1.63 & 3.44 \\
\hline \multicolumn{7}{|c|}{ Kilometres travelled: } \\
\hline Rural villages & 8.69 & 3.31 & 4.22 & 2.21 & 16.11 & 34.54 \\
\hline Urban villages & 8.52 & 2.84 & 4.49 & 1.86 & 16.94 & 34.65 \\
\hline Cities & 6.90 & 2.61 & 3.93 & 1.62 & 17.00 & 32.06 \\
\hline All classes & 7.70 & 2.77 & 4.17 & 1.78 & 16.89 & 33.31 \\
\hline \multicolumn{7}{|c|}{ Average trip length: } \\
\hline Rural villages & 14.0 & 22.1 & 5.7 & 11.6 & 10.1 & 10.5 \\
\hline Urban villages & 14.4 & 20.3 & 5.2 & 9.8 & 10.2 & 10.1 \\
\hline Cities & 11.7 & 20.1 & 4.1 & 8.5 & 10.6 & 9.2 \\
\hline All classes & 13.1 & 21.3 & 4.6 & 9.4 & 10.4 & 9.7 \\
\hline
\end{tabular}

Note: All weckdays for persons of 12 years and older.

Source: The National Bureau of Statistics, 1988

Differences are much more apparent in terms of kilometres travelled. Especially, the

${ }^{1}$ Urbanization classes: rural municipalities (at least $20 \%$ of the male work force is employed in agriculture and the built-up surface is distinctively rural); urbanized rural areas (urban villages) (less than $20 \%$ of the males employed in agriculture, but with an essentially rural appearance, and of typical commuters' residential municipalities); urban category (cities) is made up of municipalities with a high proportion of the work force in non-primary activities and a typically urban appearance. 
distance per person for home-work travel is substantially less for inhabitants of cities. The total distance travelled per person for urban dwellers is less than for the inhabitants of other settlements. This difference is attributed to the proximity of opportunities in cities.

Table 19.6 also shows that in general trip length decreases with increasing levels of urbanization. Only for leisure trips, the reverse is true. It can be seen that the average trip length varies strongly between trip purpose.

Table 19.7 shows that the car serves almost half of all trips and the share of the bicycle is remarkably high: almost $30 \%$. The modal split based on trips is almost the same for rural and urbanized villages. It also appears that in relative terms, inhabitants of cities are less reliant on cars.

TABLE 19.7

Modal split of trips for different urbanization classes (\%), (1987)

\begin{tabular}{|c|c|c|c|c|c|c|c|}
\hline $\begin{array}{l}\text { Urbanization } \\
\text { class }\end{array}$ & $\begin{array}{c}\text { Car- } \\
\text { driver }\end{array}$ & $\begin{array}{c}\text { Car- } \\
\text { passenger }\end{array}$ & Rail & $\mathrm{B} / \mathrm{T} / \mathrm{M}^{1}$ & Bicycle & Walk & Total \\
\hline Rural villages & 39 & 14 & 1 & 2 & 29 & 14 & 100 \\
\hline Urban villages & 38 & 14 & 2 & 2 & 29 & 14 & 100 \\
\hline Cities & 32 & 13 & 2 & 4 & 29 & 20 & 100 \\
\hline All classes & 35 & 14 & 2 & 3 & 29 & 17 & 100 \\
\hline \multicolumn{8}{|l|}{ Average trip } \\
\hline length $(\mathrm{km})$ & 13.5 & 17.4 & 42.3 & 9.8 & 3.0 & 1.3 & 9.7 \\
\hline
\end{tabular}

${ }^{2} \mathrm{~B} / \mathrm{T} / \mathrm{M}=\mathrm{Bus}$, Tram and Underground

See Note table 11.

Source: The National Bureau of Statistics, 1988.

The modal split for home-to-work travel is very different than that shown in Table 19.7. The share of the car-driver on a trip basis is substantially higher than average: in total $47 \%$ of all home-to-work trips are made by car. Furthermore, the difference between urbanization classes rural villages and cities is important: car-use in cities is less whereas the use of public transport is much higher than for the other two urbanization classes. Bicycle accounts for $29 \%$ of the work trips, while rail accounts for only $5 \%$. 
If calculated on the basis of distances travelled, the shares of the motorized modes are much higher at the expense of the non-motorized modes.

The geographical aspects of the travel patterns will be illustrated for the four Dutch metropolitan areas (Amsterdam, Rotterdam, The Hague and Utrecht). Trips were grouped into the geographical relations between central city, suburban ring and the surroundings. Looking to the number of trips, Table 19.8 reveals that the important relations are those within the central cities and within the suburban rings. The geographical distribution of the car trips is rather similar to that of all trips. It can be concluded that bicycle trips are heavily concentrated within the central cities and within the suburban rings. As expected, train trips are mainly long distance to and from the ex-urban areas. Other public transport trips are mainly made in the central cities.

In terms of the number of kilometres travelled different geographical distributions emerge. Taking all modes together, $70 \%$ of total distance travelled are related to trips to or from the surroundings of the metropolitan areas. The same holds for the car trips; the small share of the trips within the central cities is noticeable. Train is almost exclusively serving trips to and from the ex-urban areas.

In terms of kilometres travelled, the car is clearly the main mode in all types. The share of the bicycle is significant in local trips, whereas the train has a considerable share in the travel between the central city and the surroundings.

\subsection{Business and school travel}

Business travel relates to trips made for work purposes other than to deliver goods. It is an important travel purpose for three reasons. First, the economic value of these trips is rather high. Second, it constitutes a significant part of total travel, with a share of $10 \%$ of total distance travelled. Third, due to the high share of the car (94\%) its proportion in car travel is even larger, i.e. about $22 \%$.

The spatial analysis of business travel reveals that more than half of these trips are made within the same municipality (Wit and Jansen, 1989). On average business trips are much longer than the average trip, $21.3 \mathrm{~km}$ versus $9.7 \mathrm{~km}$.

Trips for educational purposes constitute another important category of travel. Characteristic of travel by the young is the specific availability of modes, since under 18 it is illegal to drive a car or motorcycle. The share of the bicycle is strikingly high: $85 \%$ of all school trips are made by bicycle! Even measured by distance travelled the share of the bicycle is still $54 \%$. The average length of school trips is $5 \mathrm{~km}$. B/T/M serve $15 \%$ of the trips with an average distance of $15 \mathrm{~km}$. It should be noted that in the Netherlands there are no special school bus services. 
TABLE 19.8

Distribution of modal travel and modal split in four metropolitan areas by geographical relation, based on trips and on distance travelled (in brackets), (1987/1988)

\begin{tabular}{|c|c|c|c|c|c|c|c|c|c|c|}
\hline \multirow{2}{*}{$\begin{array}{l}\text { Trip relation (two-way) } \\
\text { modes }\end{array}$} & \multicolumn{2}{|c|}{ Car } & \multicolumn{2}{|c|}{ Bicycle } & \multicolumn{2}{|c|}{ Train } & \multicolumn{2}{|c|}{$\mathrm{B} / \mathrm{T} / \mathrm{M}$} & \multicolumn{2}{|c|}{ All } \\
\hline & $\begin{array}{l}\# \\
\%\end{array}$ & $\underset{\% m}{\mathrm{~km}}$ & $\begin{array}{l}\# \\
\%\end{array}$ & $\begin{array}{r}\mathrm{km} \\
\%\end{array}$ & $\begin{array}{l}\# \\
\not \\
\not\end{array}$ & ${ }_{\%}^{\mathrm{km}}$ & $\begin{array}{l}\# \\
\%\end{array}$ & $\begin{array}{r}\mathrm{km} \\
\%\end{array}$ & $\begin{array}{l}\# \\
\%\end{array}$ & $\mathrm{~km}$ \\
\hline Modal Travel & & & & & & & & & & \\
\hline Internal central city & 31 & (11) & 46 & (42) & 3 & (1) & 62 & (37) & 37 & (13) \\
\hline Central city - suburban ring & 14 & (10) & 6 & (12) & 12 & (4) & 19 & (25) & 12 & (10) \\
\hline Central city一surroundings & 16 & (41) & 2 & (4) & 66 & (78) & 8 & (24) & 14 & (45) \\
\hline Internal suburban ring & 24 & (9) & 45 & (33) & 2 & (1) & 7 & (5) & 27 & (8) \\
\hline Suburban ring-surtoundings & 24 & (29) & 4 & (10) & 18 & (17) & 4 & (8) & 10 & (24) \\
\hline Total & 100 & $(100)$ & 100 & $(100)$ & & $(100)$ & & (100) & & $(100)$ \\
\hline
\end{tabular}

Modal Split

Internal central city

Central city-suburban ring

Central city-surroundings

Internal within suburban ring

Suburban ring-surroundings

\begin{tabular}{rrrrrrrrr}
40 & $(50)$ & 38 & $(23)$ & 1 & $(1)$ & 21 & $(25)$ & 100 \\
58 & $(60)$ & 14 & $(9)$ & 7 & $(9)$ & 20 & $(22)$ & 100 \\
58 & $(54)$ & 2 & $(1)$ & 32 & $(40)$ & 7 & $(5)$ & 100 \\
44 & $(63)$ & 52 & $(30)$ & 0 & $(2)$ & 3 & $(5)$ & 100 \\
70 & $(74)$ & 11 & $(3)$ & 12 & $(17)$ & $5(3)$ & 100 \\
\hline 49 & $(59)$ & 31 & $(7)$ & $7(23)$ & $\overline{7}(9)$ & 100
\end{tabular}

All trips

Note: Population of the metropolitan areas is distributed as follows: $46 \%$ in central cities and $54 \%$ in the suburban rings

Source: Clerx and Jansen, 1990

\subsection{Congestion patterns}

In the Netherlands most congestion appears on the motorway network in the Randstad on sections in the metropolitan fringes and not within the cities!

Time lost due to congestion on the road network has increased during the last few years from 13.8 million person hours in 1985 to 18.1 million in 1988 [NEA,1989].

About $72 \%$ of the delays are caused by lack of road capacity, $12 \%$ by accidents, $9 \%$ by road-works and $8 \%$ by other causes. Delay is largest in the morning-peak when $45 \%$ of the total delay occurs, the evening peak accounts for $35 \%$ of the total delay. The rest of the time-losses occur in off-peak-hours or in the weekends. The direct time-losses 
are valued at 1 billion Dfl. per year.

\section{INTERURBAN TRAVEL PATTERNS}

This section is confined to the interaction patterns in the Randstad, where interurban travel is defined as trips from one metropolitan area to another metropolitan area, and amounts to $11 \%$ of all trips. Table 19.9 shows the modal split in interurban travel. For commuting, public transport appears to be competitive: $30 \%$ of the trips are made by public transport.

TABLE 19.9

Daily interurban trips and modal split by purpose in the Randstad, 1986. (in thousands and \%).

\begin{tabular}{|c|c|c|c|c|}
\hline Mode & Home/work & Business & Other purpose & All purposes \\
\hline Car & $209(70)$ & $168(93)$ & $289(80)$ & $666(80)$ \\
\hline Public Transport & $89(30)$ & $12(7)$ & $71(20)$ & $172(20)$ \\
\hline Total & $298(100)$ & $180(100)$ & $360(100)$ & $838(100)$ \\
\hline Share of purposes & 36 & 21 & 43 & 100 \\
\hline
\end{tabular}

Source: Verroen et al., 1988

The car accounts for $80 \%$ of all trips in inter-urban travel. Recent developments show that the number of trips between the four largest cities in the Randstad increased more than those on any other origin-destination fair. It may therefore be concluded that the interdependence between the four cities is steadily growing [Verroen, et al., 1988].

Interaction patterns in the Randstad differ strongly by trip purpose. The pattern for home-to-work travel reveals a rather locally oriented pattern and a north and a south wing in the Randstad, around Amsterdam and Rotterdam respectively. Business travel has a much more dispersed spatial pattern. It is particularly important between the four larger cities in the Randstad. The dominance of these relations as noted above has become even stronger between 1980 and 1985. 


\section{THE INSTITUTIONAL CONTEXT}

\subsection{The policy making structure}

The political and administrative structure in the Netherlands has three levels: the central government, the provinces and the municipalities. Every four years a chamber of representatives at all levels is elected. The members of the Government, the provincial administration and the mayor and aldermen in a municipality are not members of the chamber of representatives (for instance the Parliament): the political system is meant to be dualistic. Despite three levels in the political structure, the system can be described as relatively centralist.

Concerning transport and physical planning in the Netherlands, two plans are important: the Transport Structure Plan (TSP) and the Physical Planning Report (PPR). In these plans, every 5 to 10 years, the long term strategy for transport and physical planning are laid down. The procedure is as follows: the Government introduces a policy proposal to a broad public enquiry and consultations by numerous official advisory bodies. Then the Government submits a revised proposal to Parliament which finally decides. At the moment (1992) this procedure is completed for both the Second Transport Structure Plan [Ministry of Transport, 1990] and the Fourth Report on Physical Planning [Ministry of Housing, Physical Planning and Environment, 1990].

Provinces have their own transport planning system, but receive substantial financial assistance from central government. In addition, the larger municipalities develop transport plans of a comprehensive and multimodal nature.

\subsection{The main problems and policies}

Current Dutch transport policy has three main objectives: to guarantee a minimum level of accessibility of economic centres, and at the same time maintain environmental quality and improve traffic safety.

The media currently emphasize the environmental problems as do the politicians. For instance, in 1989 a cabinet crisis on a proposal to cut tax deduction of commuting costs in order to contribute to a better environment through an expected reduction of car use, led to new elections. An important policy of the new government is to improve public transport in order to reduce (the growth of) car traffic. The government plans to invest 20 billion Dfl. in public transport in the next 20 years. Furthermore, the introduction of road pricing has been discussed. In the Second Transport Structure Plan it is proposed that road pricing in the western part of the Netherlands will be in practice after 1994. But the political and institutional opposition is very strong. Therefore road pricing will most likely not be in practice in 1994. The Ministry is now aiming at tollpricing for financing new road infrastructure. 
Many social and particularly, economic processes, depend on high accessibility, and ensuring such accessibility is generally seen as a core function of transport policy. The Netherlands play an important role in international transport and communications; the sea and airports are major nodal points in international networks. For some years the idea has come up that this country's role as a distributional hub is being endangered by inferior accessibility. This means that high-quality and congestion-free connections with the hinterland are needed for all kinds of infrastructure: road, rail, waterway and telecommunications. If no action is taken, problems will get worse. Both better public transport and road pricing are being proposed as policy instruments which hopefully will lead to maintain good accessibility of the main economic centres of the country.

\subsection{Competition between Eurocities}

It is considered vital that the Randstad keeps up with international developments. The Government is committed to actively encourage the creation of an environment within which the Randstad can compete in attracting international business. The focus is on the development of prestigious locations for offices, more expensive housing for higher-income groups, high-quality shopping areas and tourist attractions. Especially, the accessibility of the urban areas is one of the Governments main concerns.

As for other regions in the Netherlands, some economic opportunities are expected as a result of the ever-increasing international integration of production, services and capital movements. The development of one single market in the EC certainly will accelerate this process. This means that opportunities exist in areas where in the past the border has been a barrier to development, where the necessity of an international region is becoming increasingly clear.

\subsection{Some unique features of the country}

The Netherlands play an important role in international transport and communications; the sea and airports are major nodal points in international networks. The economic importance of having the largest seaport in the world, Rotterdam, is obvious.

Both the fact that there are hardly any mountains in the Netherlands and the high population density do benefit the bicycle. In Amsterdam $39 \%$ of all trips in the central city are made by bicycle [Clerx and Jansen, 1990]. On average, the bicycle is used for $29 \%$ of all trips (excluding walking).

The particular spatial structure of the Netherlands is characterized by a high overall population density and a large number of medium-sized cities at close distance of each other. Urban areas of a multicentered nature without very high concentrations of 
population and employment, like Amsterdam, Rotterdam and the Randstad as a whole, are unfavourable to public transport. It is much more expensive to provide high-quality public transport service to such areas than to monocentric and high-density cities. 